\title{
The Problem of the Conscience Clause of Healthcare Professionals in Italy in the Years 2017-2020
}

\author{
Problem klauzuli sumienia pracowników służby zdrowia we Włoszech w latach 2017-2020
}

\author{
Andrzej Kobyliński \\ Institute of Philosophy, Cardinal Stefan Wyszyński University in Warsaw, Poland \\ ORCID: https://orcid.org/0000-0003-2252-8634•a.kobylinski@uksw.edu.pl \\ Received: 09 Jul 2020; Revised: 15 Sep 2020; Accepted: 20 Sep 2020
}

\begin{abstract}
The main goal of the article is to analyse the key elements of the living will in Italy and present the dispute regarding the understanding of the conscience clause of healthcare professionals. In the country on the Tiber, a law on the living will was passed in 2017. A living will consists in the anticipatory expression of 'will', by an adult or legal guardian acting in full possession of their mental faculties, concerning the possible administration or discontinuation of certain medical therapies in the future. The conscience clause, on the other hand, means the right to refuse to take such actions, which a particular person considers to be contrary to their personal convictions. The Italian law on the living will does not contain a provision on the conscience clause. For this reason, an ethical and legal problem arose for healthcare professionals, who refused to comply with the wishes of their patients for moral or religious reasons, for example by discontinuing artificial hydration or nutrition, thus, leading to the patient's death. The ethical and legal dispute in Italy is part of a contemporary global debate on conscience clauses, euthanasia, assisted suicide, human rights, and the dignity of human life. Analyses have shown that healthcare professionals should be guaranteed the right, not to perform such medical procedures, which are contrary to their moral and religious convictions.
\end{abstract}

Keywords: living will, conscience clause, human rights, euthanasia, assisted suicide

Streszczenie: Głównym celem artykułu jest analiza najważniejszych elementów testamentu życia we Włoszech oraz prezentacja sporu dotyczącego klauzuli sumienia pracowników służby zdrowia. W kraju nad Tybrem ustawa dotycząca testamentu życia została uchwalona w 2017 r. Testament życia polega na antycypującym wyrażeniu woli przez osobę pełnoletnią lub opiekuna prawnego, dokonanym w warunkach pełnej przytomności umysłowej, dotyczącym ewentualnego podjęcia lub zaniechania w przyszłości różnego rodzaju terapii medycznych. Z kolei klauzula sumienia oznacza prawo do odmowy podjęcia tych działań, które konkretny człowiek uznaje za niezgodne z własnymi przekonaniami światopoglądowymi. Włoska ustawa o testamencie życia nie zawiera zapisu o klauzuli sumienia. Z tego powodu powstał problem etyczno-prawny dotyczący personelu medycznego, który z racji moralnych czy religijnych nie chce spełniać życzenia pacjentów, aby zaprzestać m.in. sztucznego nawadniania i karmienia, doprowadzając w ten sposób do ich śmierci. Włoski spór etyczno-prawny stanowi część współczesnej debaty o charakterze globalnym, dotyczącej klauzuli sumienia, eutanazji, samobójstwa wspomaganego, praw człowieka i godności życia ludzkiego. Przeprowadzone analizy wykazały, że pracownicy służby zdrowia powinni mieć zagwarantowane prawo do niepodejmowania tych zabiegów medycznych, które są sprzeczne z ich przekonaniami moralnymi i religijnymi.

Słowa kluczowe: testament życia, klauzula sumienia, prawa człowieka, eutanazja, samobójstwo wspomagane 


\section{Introduction}

On 1 February 2020, a National Database was launched in Italy for so-called "living wills," in some countries also called biological wills or biotestaments, i.e. advance declarations of treatment. A living will consists in the anticipatory expression of will by an adult or legal guardian - acting in full possession of their mental faculties - concerning the possible administration or discontinuation of certain medical therapies and treatments in the future which an individual does or does not wish to consent to. The decision is pre-emptive and concerns the future in which - due to old age, a road accident, unforeseen occurrences or various diseases - the patient may lose the ability to express their own will as regards the forms of treatment and life-saving procedures he or she may be submitted to.

The introduction of a new institution functioning at the Ministry of Health in the country on the Tiber was the culmination of a long social and political dispute and a long-standing process of developing legal regulations concerning the living will. A breakthrough in the matter, deeply dividing the public opinion in Italy, came in 2017 when the Parliament passed the relevant law. In anticipation of a possible future inability of self-determination, and after being provided with adequate medical information on the consequences of the choices made, the current law in force in Italy provides for every person's right to make statements concerning treatment, and to give or refuse to give consent to diagnostic tests, therapeutic decisions or particular procedures. For more than two years living wills could be made with notaries, registry offices, relevant healthcare facilities, and Italian consulates - in the case of Italian citizens living outside their homeland. After 1 February 2020, all living wills which had already been drawn up were transferred to the National Database, which is currently the only state entity authorized to collect and store such documents.
One of the most important elements of the Italian dispute around the living will is the enormously difficult issue of the conscience clause of health professionals. In the country on the Tiber, the public debate on this important ethical and legal issue has been going on for several decades now (Santoro 2019; Cembrani 2016; Kobyliński 2015a; Polito 2013). The dispute over the living will, which provides, among other things, for the possibility of discontinuing hydration and nutrition of the patient's body, is related to the vast contemporary discussion concerning euthanasia, medically assisted suicide, and the discontinuation of human life at the request of sick and elderly people. What specific legal solutions have been adopted in Italy as regards the living will? Should healthcare professionals be legally obliged to perform medical procedures that are contrary to their moral and religious convictions? What is the essence of the conscience clause of healthcare professionals? How is this hugely important ethical principle respected in the world today? The main goal of the article is to analyse the key elements of the living will in Italy and to present the ongoing philosophical and legal dispute concerning the understanding of the conscience clause of health professionals.

\section{Specificity of the Italian model of the living will}

The concept of a living will (Italian: testamento biologico; French: testament de vie; German: Patiententestament) was developed in the 1960 os in the United States. The first solutions of this kind were inspired by discussions in the medical community concerning the possibility of suspending various forms of treatment for unconscious patients on the basis of their prior medical decisions made while still in full possession of their mental faculties. The living will allows the patient to make a declaration of intent in case of a future loss of consciousness and inability to make 
decisions regarding their treatment and procedures performed to save their life.

Such a legal solution is a means by which a fully informed person declares his or her will regarding the future in terms of consent to the administration of a particular treatment in certain circumstances or, more often, refusal to give such consent. The living will is a declaration of will in which a human person indicates the healthcare treatments which they wish to receive or which should not be performed on them from the moment they are unable to adequately express their will. In the living will, the patient may indicate certain pathological situations and make both positive and negative preventive choices, as well as nominate a trusted person who will be responsible for ensuring actual compliance with the choices in a situation when the patient is not be able to do it him or herself.

In Italy, a law on the living will was adopted by the lower house of the Parliament (Italian: Camera dei Deputati) on 20 April 2017. Then, on 14. December 2017, it was passed by the upper house (Italian: Senato). The new law, most often referred to as Law No. 219/2017, entered into force on 31 January 2018. The solutions it provides for have been well received by a vast majority of the public opinion in Italy. Public sentiment on this issue was reflected in the result of the Senate vote, in which 180 parliamentarians were "for," 71 were "against", and 6 "abstained" from voting.

The new regulations allow terminally ill people to refuse treatment at the end of their lives, including artificial maintenance of vital functions, when they are unable to eat or drink on their own. No medical assistance may be initiated or continued without the patient's informed consent, and if the patient is unable to communicate, doctors must refer to the decisions set out in his or her living will. There are seven key elements which may be identified in Law No. 219/2017 (Baldini 2019):

Firstly, the legislator has provided a very precise interpretation of the principle of informed consent. On the assumption that the current legal order protects the right to life, health, but also the right to dignity and self-determination, the Law provides that no treatment may be initiated or continued without the voluntary and informed consent of the person concerned. The Law promotes and strengthens the relationship of care and trust between the patient and the doctor, founded on the principle of informed consent. The patient's family members, cohabitants or friends are also involved in the care, if the patient so wishes. Informed consent is documented in writing. Where the patient's condition does not allow it, it may also be expressed by video recording or using other suitable devices. The patient may always change his or her declared will.

Secondly, Law No. 219/2017 contains a provision on the conditions of artificial nutrition and hydration of the patient's body. Any adult person in full possession of their mental faculties has the right to accept or reject any diagnosis or treatment proposed by a doctor. In addition, they have the right to withdraw their consent at any time, even if such withdrawal involves discontinuation of treatment. This also applies to nutrition and hydration. The legislator has specified that artificial nutrition and hydration are medical treatments which consist in administering nutrients only on prescription through appropriate devices. The part of the Law concerning artificial nutrition and hydration is the most controversial provision of the entire document. The issue of the healthcare professionals' conscience clause is related primarily to the possibility of discontinuing the hydration and nutrition of patients.

Thirdly, the Law sets out the limits of medical futility, deep sedation, and discontinuation of treatment. The patient has the right to discontinue futile treatment. In the case of patients with a poor short-term prognosis or imminent death, the doctor must refrain from unwarranted persistence in the provision of care and resorting to unnecessary and disproportionate treatments. In extreme 
cases, the doctor may, with the patient's consent, apply deep palliative sedation combined with analgesic therapy.

Fourthly, Law No. 219/2017 provides an interpretation of the liability of a doctor who is obliged to respect the patient's wish to refuse or discontinue treatment. In such a situation, the doctor is exempt from civil or criminal liability. The patient may not require that the doctor provide any treatment that is unlawful, contrary to professional ethics or good clinical practice. In such a situation, the doctor does not have any professional obligations. It appears that this provision of the Law may be interpreted as an indirect recognition of the medical conscience clause. It is not entirely clear, however, how it should be understood given that elsewhere the Law obliges healthcare professionals to respect the patients' wishes expressed in their living will.

Fifthly, in the case of minors or persons who are non compos mentis, informed consent is given by parents exercising their parental responsibility or by legal guardians, taking into account the will of those entrusted to their care. Minors or legally incapacitated persons have the right to exercise their own limited ability to understand and take decisions, and should therefore be informed of their options and be afforded an opportunity to express their will.

Sixthly, any person of legal age and in full possession of their mental faculties may, in anticipation of his or her future inability of self-determination, express their pre-emptive decision regarding forms of medical treatment. The decision should be made in writing (or recorded on videotape, depending on the patient's condition) and is binding on the doctor who is obliged to comply with the content of the document.

Seventhly, Law No. 219/2017 emphasizes the joint planning of the treatment process. In the doctor-patient relationship, in view of the patient's deteriorating physical and mental condition and other negative consequences to their health, joint plans for treatment and medical care should be developed by the patient and the doctor. Such plans should be updated in accordance with the progressive development of the disease at the request of the patient or at the doctor's suggestion.

\section{Interpretation of the conscience clause}

There are three forms of conscientious objection in the Italian legal system: as regards compulsory military service (which currently does not apply in the country); as regards medical experiments on animals; and a conscience clause in the area of healthcare - mainly as regards abortion procedures and methods of artificial insemination. The Italian law on objection to military service on grounds of moral and religious convictions provides for an alternative: the state respects and recognises personal reasons for departing from the applicable law, and therefore waives possible criminal and civil consequences and offers citizens an alternative option in the form of civil service. A similar principle is reflected in the law on objection to animal testing: the act emphasises the option of using methods alternative to experiments on animals and provides for the relocation of persons working in this sector.

It is worth pointing out here that over the last decades the principle of conscientious objection to military service and the principle of conscientious objection to animal testing have caused almost no tension or controversy in the Italian society. Unfortunately, this cannot be said of the conscience clause of healthcare professionals, also known as the medical conscience clause. The bitter philosophical, legal and political dispute in this area has been going on for several decades. One of the most important elements of this dispute is the current interpretation of the medical conscience clause for pharmacists selling chemical abortion preparations, and as regards medical staff involved in chemical and surgical abortion procedures (Kućko 2016). In recent years, the issue of applying 
the principle of conscientious objection to healthcare professionals treating patients who have made a decision in their living will on the discontinuation of treatment at a certain stage of development in their disease has become a new issue in this vast worldview dispute.

Unlike the Italian laws on the termination of pregnancy of 1978 and methods of in vitro fertilization of 2004, Law No. 219/2017, does not contain any wording expressly referring to the problem of medical conscience clause. The Law obliges healthcare professionals to respect the will of the patient who does not agree for his or her body to be fed or hydrated. The Law defines hydration and nutrition as medical treatments which the patient can opt out of. Healthcare professionals are legally obliged to discontinue hydration and nutrition in accordance with the patient's will. They must discontinue artificial hydration and nutrition in any situation, if such is the will of the patient. The legislator has not provided for the possibility of applying the conscience clause in such circumstances by those healthcare professionals who, because of their religious or moral convictions, consider such action to be a form of medically assisted suicide.

After the Law's adoption in December 2017, a heated discussion began in the country on the Tiber about the absence of a conscience clause in the new legal regulations. A vast majority of critical opinions concerning the Law were formulated by representatives of the Catholic Church, which operates many healthcare facilities in Italy: hospitals, hospices, social welfare homes, care and treatment facilities, etc. The most famous Italian Catholic healthcare facilities include the two renowned institutions located in Rome: the Gemelli Polyclinic and the Bambino Gesú Children's Hospital.

The legislator did not provide for the employees of such healthcare facilities to be able to apply the conscience clause. Comments on this matter on behalf of the entire Catholic community have been made by Cardinal Gualtiero Bassetti, President of the Italian Bishops' Conference. The critical position of the Italian Catholic Church was supported, among others, by the Secretary of State of the Holy See, Cardinal Pietro Parolin. Representatives of the Catholic community stressed in the discussion that the conscience clause is a right that should be guaranteed by law (Guerra 2017). They therefore demanded that Law No. 219/2017 be supplemented with provisions to this effect. Aldo Bova (President of the National Forum of Catholic Medical Associations) and Virginio Bebber (President of the Religious Association of Socio-Medical Institutes) have publicly urged the President of the Italian Republic to prepare an appropriate legislative initiative that would lead to the introduction of a conscience clause to Law No. 219/2017.

A response to critical voices in the public discussion was provided by the Minister of Health Beatrice Lorenzin. She stated that she was personally in favour of respecting the principle of healthcare professionals' conscientious objection with regard to the living will. She announced a meeting with representatives of Catholic doctors and the adoption of appropriate guidelines on the matter. Minister Lorenzin stated that the conscience clause in the case of living will should be applied in the same way as in the case of abortion or artificial insemination (Daloiso 2017). Statements made by representatives of Catholic circles and the Minister of Health did not lead to solving the problem, however.

On the one hand, no amendments to Law No. 219/2017 have been made in the last three years. This means that the legislator still provides for no exceptions when it comes to respecting the wishes of patients expressed in their living will. On the other hand, the possibility of exercising the conscience clause may be derived indirectly both from Law No. 219/2017 and from the Code of Medical Deontology in force in Italy. Article 1.6 of the Law provides that "The doctor is obliged to respect the patient's will to refuse or opt out of treatment and 
is exempt from civil or criminal liability for taking such action. The patient may not demand treatment that is unlawful, contrary to professional ethics or good clinical practice; in the face of such requests, the doctor does not have any professional obligations." If even the Law does not mention the conscience clause expressis verbis, it seems that the application of this principle may be derived indirectly from its provisions which stipulate very clearly that the deontology of healthcare professionals may not be violated.

A similar interpretation is also provided by the Code of Medical Deontology which addresses the problem of medical care for terminally ill patients in two articles. Article 36 states: "The doctor, even at the request of the patient, must not carry out or favour procedures which are aimed at causing death." Article 37 states: "In the case of diseases with a certain poor prognosis or those which have reached the terminal phase, the doctor must limit his or her work to moral assistance and therapy aimed at avoiding unnecessary suffering by providing the patient with adequate treatment, protecting, as far as possible, their quality of life. If the patient's state of consciousness is at risk, the doctor must continue life-support therapy if she or he deems it reasonably beneficial." The Code of Medical Deontology currently in force in Italy expressly prohibits doctors not only from performing procedures aimed at causing death, but also from contributing, through various actions, even indirect ones, to the patient's death caused by him or herself or by others.

An important element of the Italian debate around the conscience clause in the context of the living will was the legislative initiative of a group of a dozen senators taken on 7 August 2019. They submitted a draft amendment to Law No. 219/2017 to the praesidium of the Senate. In document no. 1464, the senators proposed that there should be an additional provision in the Law on the conscience clause along the lines of the law on abortion and the law on the methods of artificial insemination. The proposal also took into account the difficulties of healthcare facilities of the Catholic Church in implementing Law No. 219/2017 due to their particular religious and moral inspiration. Therefore, the amendment excluded all private healthcare facilities from the application of the Law. The group of senators' legislative initiative was not approved by the Senate, and consequently Law No. 219/2017 is still in force in its original wording.

The dispute over the conscience clause of healthcare professionals in the country on the Tiber became particularly intense in 2019 and 2020 due to judgment no. 242 of the Italian Constitutional Tribunal of 22 November 2019. The judgment was rendered in a case considered by the Court in two public hearings, on 23 October 2018 and 24 September 2019, and was concerned with examining the legality of Article 580 of the Criminal Code in the part which specifies that procedures defined as assisted suicide are punishable. The case was referred to the Constitutional Tribunal by a court in Milan which was trying a case against the politician and social activist Marco Cappato, accused of facilitating the suicide of Fabiano Antoniani - known as DJ Fabo - by helping him travel to the Swiss clinic "Dignitas" to have his life terminated on request.

In its judgment, the Constitutional Tribunal held that under certain conditions, especially at the request of the patient, assisting a person in bringing about their death is not punishable, thereby indirectly recognising the right to medically assisted suicide. Consequently, Article 580 of the Criminal Code was declared unconstitutional. Moreover, the Court instructed the Parliament to draw up a comprehensive law on the "end of life", which the judges considered necessary. It is worth noting here that the judgment of the Constitutional Tribunal is consistent with the provisions of Law No. 219/2017: if it is permissible to shorten the patient's life by 
discontinuing artificial nutrition, hydration and breathing, it would hardly be possible to justify a ban on other means leading to the death of a sick or elderly person, for example by administering a lethal preparation through a drip or syringe.

In the context of the Constitutional Tribunal's judgment, the discussion on the conscience clause of healthcare professionals in Italy rekindled once again (Scandroglio 2019). The Tribunal ruled that the decision on the non-conformity of Article 580 of the Criminal Code with the Italian Constitution is limited to excluding the penalty for assisting suicide in certain cases, without requiring doctors to provide such assistance. Therefore, the decision whether to comply with the patient's request is made in the conscience of each individual doctor. On the one hand, the Tribunal recognised the conscience clause of healthcare professionals, stating that the doctor is not obliged to assist the patient in committing suicide and therefore there is no legal obligation relating to assisted suicide. On the other hand, although an individual doctor may object, the patient's constitutionally protected right to assistance in death must be satisfied, and therefore there is a subjective right to assisted suicide. Therefore, in the case of conscientious objection by a particular doctor, the hospital will have to fulfill this obligation. This is the same legal situation as in the case of the termination of pregnancy - Italian law respects the conscience clause of healthcare professionals, but also takes into account the woman's right to abortion. The Constitutional Tribunal has therefore recognised the principle of conscientious objection by medical staff, and not by healthcare facilities.

Much seems to suggest that in the coming years medically assisted suicide and termination of life on request may become legalised. Today, the public debate around the principle of conscientious objection by healthcare professionals in the context of the living will automatically becomes an ethical and legal dispute over the application of the medical conscience clause in various situations related to suffering, dying, suicide, assistance in suicide, active euthanasia, passive euthanasia, or termination of life on request. Given the Constitutional Tribunal's judgment of 22 November 2019, it appears that relevant legal regulations will soon be enacted in Italy to introduce a uniform understanding of the medical conscience clause with regard to abortion, methods of artificial insemination and various forms of termination of life at the patient's request.

It is worth noting at this point that in 2019, four thousand Italian Catholic doctors declared they would exercise the principle of conscientious objection also if the Parliament passed a law on medically assisted suicide. Filippo Anelli, President of the National Federation of Surgeons and Dentists, appealed to the legislator who would be regulating this difficult issue in the future to exempt doctors from the obligation to administer lethal preparations to their patients. Anelli stated that if the Italian Parliament were to introduce new solutions, it should not be doctors but state officials appointed specifically for this role who should directly assist in the patients' suicide and termination of life on request. Doctors should remain doctors, so they must not participate in shortening the lives of their patients, as their mission is to alleviate their suffering, protect their life and their physical and mental health.

\section{The principle of conscientious objection and human rights}

The principle of conscientious objection is part of the fundamental and inalienable human right to freedom of conscience and religion (Meaney and Casini 2016). In recent years, the term "religious freedom" has been increasingly used instead of other synonymous phrases such as "freedom of conscience and religion" or "freedom of conscience and confession". Religious freedom is rooted in the very dignity of the human person. It is the source and pinnacle 
of all human rights. Freedom of conscience and religion is by its very nature a right that should be guaranteed to everyone regardless of race, colour, religion or worldview they embrace.

The conscience clause may also be defined as the right to refuse to participate in activities which a particular person considers morally wrong and contrary to his or her convictions (Sartea 2017). It specifically concerns procedures such as assisting in the suicide of the elderly or terminally ill, sterilisation, surgical or pharmacological abortion, prenatal diagnosis aimed at the killing of weaker and ill children, the use of human embryos for laboratory testing, genetic manipulation, prescribing and selling abortifacients, etc.

The conscience clause is rooted in the belief that individual freedom of conscience takes precedence over the provisions of statutory law. Its deepest justification is the freedom and dignity of the human person. Unfortunately, in many countries around the world various attempts have been made recently to limit or entirely negate the conscience clause. More and more often now some researchers and columnists talk about a global attack on the conscience clause (Dovico 2020). Many governments seek to exclude the possibility of exercising the principle of conscientious objection by representatives of various professions. The new approach to the conscience clause is linked primarily to a new understanding of human rights. For more than a dozen years now, we have been witnessing the emergence of fourth generation rights, also called new human rights. Unlike previous generations of human rights, new human rights do not emphasize what man is entitled to in political or social terms, but focus essentially on ethical and worldview issues (Kobyliński 2009).

New human rights negate the need to refer to human nature and natural law. Their advocates question the principle that every legal order is legitimized by natural law (Rozmarynowska 2018; Waleszczyński
2019). In this context, the emergence of fourth generation rights represents a major breakthrough in the understanding of fundamental rights, which is reflected in expanding the catalogue of rights contained in the 1948 Universal Declaration of Human Rights to include entirely new phenomena (euthanasia, assisted suicide, abortion, choice of sexual orientation, reproductive rights, etc.). One consequence of this reinterpretation of human rights is the limitation of the applicable scope of the conscience clause in many countries.

In early 2020 , European media commented on the case of two Swedish midwives: Ellinor Grimmark and Linda Steen. Both women worked as nurses, and after completing their post-graduate studies, they wanted to start working as midwives. Unfortunately, at several facilities - despite staff shortages - they were denied employment. The only reason they were provided was their refusal to participate in abortion procedures, which are permitted in the Swedish legal system. There is de facto no medical conscience clause in Sweden. In practice, this means that doctors, nurses, midwives and other medical staff cannot refuse to participate in abortion procedures, for instance.

Grimmark and Steen began their legal battle many years ago. They have received legal assistance from the Alliance Defending Freedom, which takes various actions to promote the right to religious freedom and the principle of conscientious objection. Sadly, the Swedish courts of all instances rejected the arguments put forward by the two midwives. In their judgments they stated that the employer may require midwives to perform all activities which are in accordance with Swedish law.

In the final stage of their long-running legal battle, Grimmark and Steen filed their complaint with the European Court of Human Rights in 2017. On 12 March 2020 , the Court in Strasbourg delivered its judgment in their case. The complaints of the Swedish midwives were rejected. On the one hand, the Strasbourg Court 
acknowledged that preventing the midwives from practising their profession was an interference with their freedom of conscience and religion; on the other hand, the judges concluded that such interference was necessary and proportionate in view of the access to abortion guaranteed under Swedish law.

For several years, an especially difficult dispute concerning the conscience clause has also been going on among members of the World Medical Association (Cancelli 2018). Some of them are very strongly for drastically limiting the use of the medical conscience clause globally. In early 2018 , this was pointed out by John Lee, President of the International Federation of Catholic Physicians' Associations, who sent a very critical letter to the authorities of the World Medical Association. Lee said that the organization's actions could lead to a situation where in many cases the exercise of the doctors' right to conscientious objection would become impossible and the protection of human life would cease to be for them the highest law. In his view, this leads to a global promotion of a very liberal approach to the issue of abortion and euthanasia. One element of this policy is exerting pressure on the positive laws of individual countries. The advocates of liberal solutions in this area encourage the governments of many countries to adopt new legal solutions that would, on the one hand, facilitate the citizens' access to abortion and euthanasia, and, on the other hand, restrict the right of medical staff to use the conscience clause (Kobyliński 2015b).

In recent years, the debate around the conscience clause has also been going on at the United Nations. The UN Human Rights Committee, which considers access to abortion and euthanasia to be part of fundamental rights, is particularly active in this area. According to the representatives of this organisation, the conscience clause used by medical staff in some countries prevents, among other things, women's effective access to abortion procedures. The
UN officials' treatment of legal abortion as a human right raises many difficult questions about the functioning of international law, the modern understanding of morality, and the future of the human race in the coming centuries (Marin 2017).

\section{Conclusion}

The debate held in Italy around the conscience clause of health professionals is part of a great global worldview dispute (Mendz 2016). Unfortunately, in many countries various attempts have been made more and more often recently at restricting the exercise of the conscience clause, whose most profound substantiation is founded on human dignity and the right to freedom of conscience and religion. Healthcare professionals should be guaranteed the right to refuse to perform such medical procedures as are contrary to their moral and religious convictions.

Much seems to suggest that the philosophical and political dispute over the conscience clause will become even more heated in the coming decades. In 2019, the Union of Atheists and Rationalist Agnostics launched a major advertising campaign against the conscience clause in Italy. The organizers presented their views in the media and on large outdoor billboards. The main goal of this action was to convince the public that the conscience clause should be completely eliminated from the Italian legal order, as it had been done in Sweden. Similar demands are being made in many other countries, including Poland. On 3 February 2019, the founding convention of the "Spring" political party was held in the country. In his programme speech, the party's president Robert Biedron called for the removal of the conscience clause from the Polish legal order.

The questioning of the principle of conscientious objection is a confirmation of the modern crisis of bioethics and biolaw, the deepest manifestation of which is the prevalence of ethical utilitarianism in many communities (Scandroglio 2018). In the debate on the conscience clause in the 
context of the living will, medically assisted suicide, or termination of life on request, the category of the quality of human life is increasingly replacing the conviction about its inviolable dignity. The justification of shortening the lives of terminally ill patients by an unsatisfactory quality of life is typical of those versions of bioethics and bio-law which are not inspired by a personalist vision of a man based on a metaphysical foundation. Ethical utilitarianism is linked to the concept of legal positivism which says that legal norms established by a competent authority do not need to be based on the foundation of natural law and the dignity of the human person.

\section{Bibliography}

Baldini, Gianni. 2019. "La pianificazione condivisa delle cure: prime riflessioni a margine della 1. 219/2017." In La relazione di cura dopo la legge 219/2017. Una prospettiva interdisciplinare, edited by Massimo Foglia, 129-147. Pisa: Pacini Editore.

Cancelli, Ferdinando. 2018. "Di fronte alle politiche su aborto ed eutanasia. In pericolo l'obiezione di coscienza." L'Osservatore Romano 158(39): 1.

Cembrani, Fabio, and Gianluca Cembrani. 2016. L'obiezione di coscienza nella relazione di cura. Torino: Edizioni SEEd.

Daloiso, Viviana. 2017. "Obiezione do coscienza? Per le Dat sarà garantita.” Avvenire 50(301): 10.

Dovico, Ermes. 2020. “Attacco globale all'obiezione di coscienza." La Nuova Bussola Quotidiana, March 17, 2020. https://www.lanuovabq.it/it/ attacco-globale-allobiezione-di-coscienza.

Guerra, Marco. 2017. "Lo Stato contro gli ospedali cattolici, il conflitto che verrà." La Nuova Bussola Quotidiana, Dicember 22, 2017. http://lanuovabq. it/it/lo-stato-contro-gli-ospedali-cattolici-ilconflitto-che-verra.

Kobyliński, Andrzej. 2009. “The Genesis and Nature of «New Human Rights»." In Etyczne wymiary praw człowieka, edited by Ryszard Moń and Andrzej Kobyliński, 133-142. Warszawa: Wydawnictwo UKSW.

Kobyliński, Andrzej. 2015a. "Aspekty etyczno-prawne sporu o klauzulę sumienia we Włoszech w latach 2014-2015." Studia Ecologiae et Bioethicae 13(3): 25-48. https://doi.org/10.21697/seb.2015.13.3.02.
Kobyliński, Andrzej. 2015b. "Nowy humanizm czy posthumanizm? Aspekty etyczno-prawne legalizacji eutanazji na świecie w latach 20002015." Studia Ecologiae et Bioethicae 13(4): 85-114. https://doi.org/10.21697/seb.2015.13.4.04.

Kućko, Wojciech. 2016. Etica dei farmacisti in Italia. Verso una nuova comprensione e prassi alla luce della bioetica personalista. Roma: Academia Alfonsiana.

Marin, Francesca. 2017. "Il fine vita e l'attribuzione di responsabilità morale." Medicina e Morale 66(5): 617-632.

Meaney, Joseph, and Marina Casini. 2016. "I diritti umani alla vita e alla coscienza e la risoluzione dei conflitti dei diritti umani." Medicina e Morale 65(5): 633-653.

Mendz, George L. 2016. “Obiezione di coscienza e relativismo morale." Medicina e Morale 65(1): 39-55.

Polito, Pietro. 2013. Elogio dell'obiezione di coscienza. Milano: Biblion Edizioni.

Rozmarynowska, Karolina. 2018. "Podmiotowe źródła obywatelstwa." Seminare 39(2): 35-44. http://doi.org/10.21852/sem.2018.2.03.

Santoro, Roberta. 2019. Obiezione do coscienza e appartenenza religiosa: prime riflessioni sui profili di novità. Bari: Cacucci Editore.

Sartea, Claudio. 2017. “Obiezione vostro onore. Un problematico consensus statement sull'obiezione di coscienza sanitaria." Medicina e Morale 66(1): 63-81.

Scandroglio, Tommaso. 2018. "Se la bioetica degenera nel miglior interesse che verrà." La Nuova Bussola Quotidiana, April 19, 2018. http://www.lanuovabq. it/it/se-la-bioetica-degenera-nel-miglior-interesseche-verra

Scandroglio, Tommaso. 2019. "Suicidio, la Consulta apre all'obiezione di coscienza. Che non reggerà." La Nuova Bussola Quotidiana, November 24, 2019. https://lanuovabq.it/it/suicidio-la-consulta-apreallobiezione-di-coscienza-che-non-reggera.

Waleszczyński, Andrzej. 2019. "Między troską a sprawiedliwością: Virginii Held poglądy na wspólnotę polityczną." Roczniki Filozoficzne 67(3): 115-135. 